\title{
Hodnotenie uplatňovania myšlienky udržatel'ného rozvoja vo výchovno-vzdelávacom procese na základných školách v meste Banská Štiavnica
}

\author{
Viera Chrenščová, Jana Škvarková \\ Envigogika 2013/VIII/1- Recenzované články/ Reviewed Papers \\ Publikováno/Published 31 05. 2013
}

DOI: http://dx.doi.org/10.14712/18023061.291

\begin{abstract}
Abstrakt
Rozvoj environmentálnej výchovy a vzdelávania patrí $v$ súčasnosti $k$ stálym požiadavkám na všetkých stupňoch škôl v Slovenskej republike. Významnou úlohou školy je dlhodobo a systematicky ovplyvňovat' a usmerňovat' spôsob myslenia žiakov, zvyšovat' environmentálne vedomie a na princípe hromadenia životných skúseností smerovat́ k udržatel'nému rozvoju spoločnosti.

Článok prináša výsledky analýzy stavu uplatňovania filozofie udržatel'ného rozvoja vo výchovno-vzdelávacom procese na základných školách $v$ meste Banská Štiavnica na základe vyhodnotenia súboru indikátorov udržatel'ného rozvoja škôl za školský rok 2011/2012.
\end{abstract}

\section{Kl'účové slová}

Udržatel'ný rozvoj, indikátory udržatel'ného rozvoja, vzdelávanie, základné školy, environmentálna výchova

\section{Abstract}

Development of environmental education is currently required at all levels of education in Slovakia. The school plays an important role in long-term and systematic influence and guidance of pupils thinking and in increasing environmental consciousness. The role of the school is also to support sustainable development of society with the principle of accumulation of life experiences.

The article presents results of analysis focused on state of sustainable development implementation within the educational process at primary schools in the city of Banská Štiavnica by the means of evaluation of the sustainable development indicators for academic year 2011/2012.

\section{Key words}

sustainable development, indicators of sustainable development, education, primary schools, environmental education 


\section{Úvod}

Problematika udržatel'ného rozvoja je teoreticky rozpracovaná a podložená už vyše 20 rokov. Postupne sa stala súčastou aj školského systému, čo je vel'mi dôležité, nakolko výchova a vzdelávanie je najlepším predpokladom dosiahnutia filozofie udržatel'ného rozvoja. Výchova k udržatel'nému rozvoju prispieva k zmene postojov a hodnôt, k rozvoju kritického myslenia a zvýšeniu informovanosti. Vedie $k$ zmene $v$ názoroch l'udí a tak im umožňuje urobit' svet zdravším, bezpečnejším a prosperujúcejším, zvyšujúc tým kvalitu života (Stratégia EHK OSN..., 2005). Ide však o dlhodobý proces, vyžadujúci si nevyhnutne zmenu správania sa človeka nielen k prírode a prírodným zdrojom, ale aj $\mathrm{k}$ sebe samému. Dosiahnutie udržatel'nosti je nemyslitel'né bez toho, aby došlo $k$ podstatnej zmene vnímania a prežívania vzt́ahu človeka k životnému prostrediu. Ved' udržatel'ný rozvoj (UR) znamená predovšetkým zásadnú zmenu celého doterajšieho programu správania l'udí voči sebe navzájom a voči celému komplexu fenoménov, súhrnne označovaných svet alebo životné prostredie (Halašová, 2011).

Výchova k pozitívnemu vztáahu k prírode a životnému prostrediu má na Slovensku dlhú a bohatú históriu. Spočiatku bola založená predovšetkým na šetrnom prístupe a spätosti l'udí s prírodou, neskôr sa rozšírila v súvislosti s narastajúcimi ekologickými problémami o nové environmentálne témy, ktoré súviseli so znečistovaním životného prostredia, s potrebou ochrany prírody aj l'udského zdravia. V sedemdesiatych rokoch 20. storočia vzniká environmentálna výchova ako výchova k ochrane a tvorbe životného prostredia alebo ako výchova k ochrane prírody (Šimonovičová, Šudý et al., 2008; Cviková et al., 2010).

Súčast'ou školského systému v SR je od roku 1996 environmentálna výchova, kedy vstúpili do platnosti nad-predmetové osnovy environmentálnej výchovy - Environmentálne minimum (Kelcová, Ugrocká, 1996). Vznikol tým oficiálny rámec definujúci formálne vzdelávanie environmentálnej výchovy.

Základy koncepčnej environmentálnej výchovy v Slovenskej republike položila Koncepcia environmentálnej výchovy a vzdelávania v SR v roku 1997. V súvislosti s prijatím Stratégie EHK OSN pre výchovu k trvalo udržatel'nému rozvoju (2005) a novej Koncepcie environmentálnej výchovy a vzdelávania na všetkých stupňoch škôl $v$ SR a v systéme celoživotného vzdelávania (2006) sa pozornost' sústred'uje na potrebu zvýšenia kvality edukácie v oblasti environmentálnej výchovy, inovácie environmentálnej výchovy o aspekt výchovy k udržatel'nému rozvoju a začleňovanie výchovy $\mathrm{k}$ udržatel'nému rozvoju do formálnych systémov vzdelávania, do všetkých vyučovacích predmetov a vzdelávacích programov, a tiež do neformálneho a informálneho vzdelávania.

Výrazným krokom v oblasti environmentálneho vzdelávania na Slovensku bola školská reforma a prijatie nového zákona č. 245/2008 Z. Z. o výchove a vzdelávaní (účinný od 1. septembra 2008). Školskou reformou sa učebné osnovy environmentálnej výchovy - Environmentálne minimum (1996) nahradili prierezovou témou Environmentálna výchova (ŠVP-EV_Pt, 2009), ktorej úlohou je viest' žiakov ku komplexnému pochopeniu vzájomných vzt́ahov medzi organizmami a vzt́ahom človeka $k$ životnému prostrediu a k potrebe prechodu $k$ udržatel'nému rozvoju. So snahou o udržatel'ný rozvoj sa rozmer environmentálnej výchovy obohacuje tiež o globálne environmentálne témy, ktorých ciel'om je viest' k zodpovednosti za správanie sa, ktoré zabezpečí udržatel'ný život na Zemi, prispôsobenie sa životného štýlu smerujúceho k zachovaniu a zlepšeniu životného prostredia pre d'alšie generácie (ŠVP - EV_Pt, 2009). Témy udržatel'ného rozvoja vedú k zvyšovaniu povedomia o globálnych environmentálnych problémoch a globálnych problémoch sveta, ktoré sa týkajú každého jednotlivca, k rozvoju jeho kritického myslenia a k hlbšiemu porozumeniu oblastí a tém, ktoré sa týkajú celého sveta. Poskytujú priestor na zmenu postojov jednotlivca, skupín, komunít a posilňujú uvedomenie si vlastnej úlohy vo svete. Zdôrazňovaný je prístup globálneho rozvojového vzdelávania, ktorý vedie k hlbšiemu porozumeniu rôznorodosti a nerovnosti 
vo svete, $\mathrm{k}$ príčinám ich existencie a možnostiam riešenia problémov $\mathrm{s}$ nimi spojených (Národná stratégia pre globálne vzdelávanie na obdobie rokov 2012 - 2016).

Od Konferencie OSN o životnom prostredí a rozvoji v roku 1992 a od vyhlásenia Dekády výchovy k UR OSN na roky 1995 - 2014 sa celosvetovo vo výchovno-vzdelávacích systémoch a voblasti riadenia škôl urobil v intenciách UR značný pokrok. $\mathrm{Na}$ medzinárodnej, lokálnej úrovni, na úrovni mimovládnych a občianskych združení, ale i vládnych inštitúcií, vznikajú početné iniciatívy, čiastočne alebo komplexne implementujúce aktuálnu environmentálnu politiku do školského prostredia. Vznikajú školské programy, vyznačujúce sa rôznou úrovňou uplatňovania Miestnej agendy 21, environmentálnych manažérskych systémov a akreditačných schém (Šimonovičová, Šudý et al., 2008). K celosvetovo najznámejším patria napr.: Eko-školy v Európe (www.ecoschools.org, 2013), Zelené školy vo Švédsku (www.hsr.se, 2013) a v Kanade (www.greenschools.ca, 2013), Trvalo udržatel'né školy v Austrálii (www.environment.gov.au, 2013) a USA (www.seer.org, 2013), Enviro-školy na Novom Zélande (www.enviroschools.org.nz, 2013aprogramy Ekologickej stopy (www.footprintnetwork.org, 2013; http://ekostopa.sk/, 2013) a mnohé d'alšie. K príkladom čiastočného uplatňovania princípov UR v činnosti a filozofii škol možno zaradit' aj niektoré alternatívne, Zdravé, Otvorené školy, školské programy a projekty, ktoré sú zamerané na zvyšovanie environmentálneho povedomia mládeže (Šimonovičová, Šudý et al., 2008).

So snahou o uplatňovanie filozofie udržatel'ného rozvoja rastie aj potreba zist'ovat' pokrok a pravidelne vyhodnocovat' jeho ukazovatele (indikátory) vo vzdelávacom procese.

Postupne sa vytvárajú a aplikujú rôzne hodnotiace a certifikačné schémy, založené na práci s relevantnými indikátormi. Vzniká vel'ká množina rôznorodých indikátorov, ktoré vyplývajú z priorít a špecifík školských systémov, národných koncepcií UR, projektov a programov. Napríklad školy vo Velkej Británii podliehajú internému hodnoteniu procesu zlepšovania kvality, ktorého integrovanou súčast'ou je Dotazník hodnotenia UR školy, ktorý slúži na zist́ovanie a zaznamenávanie schopnosti školy prezentovat' UR. Pracovná skupina z austrálskej Iniciatívy trvalo udržatel'ných škôl naopak vypracovala súbor 32 indikátorov, ktorý sa zameriava na meratel'né aspekty v siedmich oblastiach (výchovno-vzdelávacie, environmentálne, ekonomické, pre hospodárenie s vodou, elektrinou, odpadom, pre školský pozemok), ktoré školy na ceste k UR môžu menit' a zlepšovat' (Šimonovičová, Šudý et al., 2008). Medzinárodný program Eko-školy (Eco-schools) vznikol v roku 1994 a je zameraný na implementáciu Miestnej agendy 21 (www.eco-schools.org, 2013). S podporou Európskej komisie sa implementoval v Dánsku, Grécku, Nemecku a vo Velkej Británii. Odtial' sa vel'mi rýchlo rozšíril do celého sveta. Každá krajina si v rámci svojho projektu pripravuje separátny systém hodnotenia s vlastnými indikátormi vo vybraných oblastiach činnosti školy. Na Slovensku bol ako súčast' európskeho programu Eko-školy vypracovaný projekt "Zelená škola" (Živica, 2013), ktorý má formu sút́aže. Stanovených bolo 57 indikátorov rozdelených do ôsmich oblastí, z čoho 25 (najväčšia skupina) je venovaná výchovno-vzdelávaciemu procesu. Ďalšími oblastáami sú: voda, odpad, energia, doprava, zeleň, ochrana prírody a humánny prístup ku zvieratám, používanie ekologických materiálov a produktov, stravovanie. Každý indikátor obsahuje konkrétne úlohy, za splnenie ktorých dostávajú školy príslušný počet bodov podla kvality prevedenia.

Súbor indikátor UR škôl prináša aj práca autorov Šimonovičová, Šudý et al. (2008): Indikátory trvalo udržatel'ného rozvoja pre školy. Práca ponúka spolu 135 indikátorov ako nástroj pre objektívne zistóovanie a hodnotenie stavu uplatňovania UR $v$ slovenských školách. Indikátory sú členené do 4 hlavných oblastí a 14 kategórii a ich podkategórií. Ide o oblasti manažmentu, výchovy a vzdelávania, zdravia a sociálneho prostredia a indikátory prevádzky. Metodika práce je založená na pravidelnom vyhodnocovaní, pričom 1 cyklus hodnotenia zodpovedá 1 školskému roku a pozostáva z niekolkých postupných krokov, ktorými sú: meranie, identifikácia, váženie a indexovanie.

Index UR školy sa vypočíta porovnaním tohoročného čísla s predchádzajúcim rokom podl'a rovnice: Index UR rovná sa podielu predminuloročnej sumy váženia indikátorov a minuloročnej sumy váženia indikátorov. Hodnota indexu menšia ako 1 znamená, že 
správanie školy smerom k UR sa zlepšuje, zatial' čo hodnota väčšia ako 1 poukazuje na opačný trend.

\section{Ciel’ skúmania, skúmaný súbor, použitá metóda, realizácia prieskumu}

Predkladaný článok prináša výsledky výskumu uplatňovania myšlienky udržatel'ného rozvoja vo výchovno-vzdelávacom procese na základných školách $v$ meste Banská Štiavnica.

Ciel'om výskumu bola analýza stavu uplatňovania myšlienky udržatel'ného rozvoja (UR) vo výchovno-vzdelávacom procese na všetkých základných školách (ZŠ J. Kollára, ZŠ J. Horáka a Cirkevná ZŠ sv. F. Assiského) v meste Banská Štiavnica.

Výskum vychádzal z metodiky Šimonovičová, Šudý et al. (2008).

$\mathrm{Na}$ základe súboru indikátorov výchovy a vzdelávania (19) navrhnutého v práci Šimonovičová, Šudý et al. (2008) sa zist́oval a hodnotil stav uplatňovania udržatel'ného rozvoja v školách vo výchovno-vzdelávacom procese v troch kategóriách:

I. Predmetová výchova a vzdelávanie,

II. Mimoškolská výchova a vzdelávanie,

III. Kvalita výchovy a vzdelávania (tab. 1). Výskum bol realizovaný v mesiacoch január - február 2013 a získané údaje sa vztáahujú k školskému roku 2011 2012.

Tab. 1 Indikátory udržatel'ného rozvoja vo výchovno-vzdelávacom procese

\begin{tabular}{|l|l|}
\hline $\begin{array}{l}\text { Indikátory udržatel'ného rozvoja v troch } \\
\text { kategóriách }\end{array}$ & $\begin{array}{l}\text { Počet } \\
\text { indikátorov }\end{array}$ \\
\hline I. PREDMETOVÁ VÝCHOVA A VZDELÁVANIE & 3 \\
\hline II.MIMOŠKOLSKÁ VÝCHOVA A VZDELÁVANIE & 9 \\
\hline III. KVALITA VÝCHOVY A VZDELÁVANIA & 7 \\
\hline Súbor indikátorov výchovy a vzdelávania & 19 \\
\hline
\end{tabular}

(Zdroj: Šimonovičová, Šudý et al., 2008)

Hodnotenia súboru indikátorov v 3 kategóriách názorne vyjadrujú tabul'ky 2, 4, 6, v ktorých je pre každý indikátor uvedená jeho definícia, charakteristika a spôsob hodnotenia. Jednotlivé položky tabul'ky podl'a práce Šimonovičová, Šudý et al. (2008) tvorí:

- Indikátor - špecifické vyjadrenie, ktoré poskytuje informácie o úrovni školy v oblasti implementácie a realizácie filozofie UR vo výchovno-vzdelávacom procese. Definuje charakteristiky (činnosti, aktivity, javy a prvky) preukazujúce uplatňovanie UR v škole. Ide o kvalitatívny indikátor, zist́ujúci existenciu, stav, alebo kvantitatívny indikátor merajúci rozsah, počet, frekvenciu, intenzitu a pod. $v$ hodnotenom období t.j. počas jedného školského roku.

- Charakteristika indikátora - bližšie popisuje indikátor, povahu a charakter posudzovaných činností ako aj spôsob hodnotenia. Hodnotí význam z hladiska UR a obsahuje konkrétne požiadavky na prácu školy. 
- Kritériá hodnotenia - slúžia pre kvantifikáciu indikátorov podla jednotnej stupnice $\mathrm{s}$ hodnotami 0, 1, 2 a pre hodnotenie ich významnosti z hladiska vplyvu na úroveň implementácie UR do výchovy a vzdelávania na škole. Pričom:

0 = žiadny alebo zanedbatel'ný vplyv na UR,

1 = stredne velký vplyv na UR,

2 = vel'ký vplyv na UR.

Hodnota 0 vyjadruje najhoršiu možnost' a hodnota 2 naopak tú najlepšiu alternatívu danej činnosti.

Použitý metodický postup (Šimonovičová, Šudý et al., 2008) bol autorkami príspevku upravený nasledovne:

- Inovované boli niektoré charakteristiky indikátorov, ako aj kvantitatívne charakteristiky jednotlivých hodnotiacich kritérí. Charakteristika indikátorov bola bližšie špecifikovaná a doplnená o globálny aspekt UR.

- $\quad V$ záverečnom kroku namiesto indexovania sa pristúpilo $k$ vyhodnoteniu na základe percentuálnych hodnôt vypočítaných zo súm získaných v jednotlivých kategóriách. Každá kategória zo súboru indikátorov je slovne hodnotená vo vyhodnocovacích tabulkách $(3,5,7)$. Slovné vyhodnotenie (vel'mi dobré, dobré, uspokojivé, neuspokojivé) vyjadruje stupeň úrovne UR na základe priradenia súčtov bodov (vyjadrených $\vee \%)$ jednotlivých indikátorov do hodnotiacich intervalov $(v \%)$ pre oblast' výchovy a vzdelávania v príslušných hodnotených kategóriách.

\section{Celkové hodnotiace intervaly v \% a k nim slovné hodnotenie}

$$
\begin{aligned}
& 80-100 \% \quad \text { vel'mi dobré } \\
& 60-79,9 \% \text { dobré } \\
& 40-59,9 \% \text { uspokojivé }
\end{aligned}
$$

menej ako 39,9\% neuspokojivé

- V rámci kvantifikácie indikátorov (pri niektorých indikátoroch) sa pristúpilo ku korekcii, nakolko $v$ pôvodnej metodike neboli jednoznačne určené percentuálne intervaly a tak ich nebolo možné jednoznačne identifikovat'.

\section{Analýza a interpretácia výsledkov}

Prvá kategória Predmetová výchova a vzdelávanie bola hodnotená na základe 3 indikátorov: Zaradenie predmetov UR do učebných plánov, Úprava učebných osnov pre UR a Úprava tematických plánov pre UR. Hodnotenie súboru indikátorov v prvej kategórií názorne dokumentuje tabulka 2. 
Tab. 2 Hodnotenie základných škôl podl’a indikátorov I. Predmetová výchova a vzdelávanie za školský rok 2011/2012

\begin{tabular}{|c|c|c|c|c|c|}
\hline \multirow[b]{2}{*}{ INDIKÁTOR } & \multirow[b]{2}{*}{$\begin{array}{l}\text { CHARAKTERISTIKA } \\
\text { INDIKÁTORA }\end{array}$} & \multirow[b]{2}{*}{$\begin{array}{l}\text { HODNOTIACE } \\
\text { KRITÉRIUM }\end{array}$} & \multicolumn{3}{|c|}{ NÁZOV ZÁKLADNEJ ŠKOLY } \\
\hline & & & $\begin{array}{l}\text { ZŠ } \\
\text { KOLLÁRA }\end{array}$ & $\begin{array}{l}\text { ZŠ } \\
\text { HORÁKA }\end{array}$ & $\begin{array}{l}\text { ZŚ } \\
\text { CIRKEVNÁ } \\
\text { ASSISKÉHO }\end{array}$ \\
\hline \multirow{3}{*}{$\begin{array}{l}\text { Zaradenie } \\
\text { predmetov } \\
\text { UR } \\
\text { do } \\
\text { učebných } \\
\text { plánov } \\
\text { školy }\end{array}$} & \multirow{3}{*}{$\begin{array}{l}\text { Učebné plány } \\
\text { obsahujú } \\
\text { nepovinne volitel'né } \\
\text { predmety s témami } \\
\text { UR, s globálnymi } \\
\text { témami. }\end{array}$} & $\begin{array}{l}0 \text { - nezaradené } \\
\text { predmety UR } \\
\text { do učebných } \\
\text { plánov }\end{array}$ & \multirow[t]{3}{*}{1} & \multirow[t]{3}{*}{1} & \multirow[t]{3}{*}{1} \\
\hline & & $\begin{array}{l}1 \text { - zaradený } \\
\text { jeden predmet } \\
\text { UR do učebných } \\
\text { plánov }\end{array}$ & & & \\
\hline & & $\begin{array}{l}2 \text { - } \text { zaradené } \\
\text { dva a viac } \\
\text { predmetov UR } \\
\text { do uč. plánov }\end{array}$ & & & \\
\hline \multirow[t]{3}{*}{$\begin{array}{l}\text { Úprava } \\
\text { učebných } \\
\text { osnov pre } \\
\text { UR }\end{array}$} & \multirow{3}{*}{$\begin{array}{l}\text { Zaradenie tém UR } \\
\text { a globálnych tém } \\
\text { do obsahu učiva } \\
\text { jednotlivých } \\
\text { vyučovacích } \\
\text { predmetov } \\
\text { (úprava učebných } \\
\text { osnov predmetov } \\
\text { v percentách). }\end{array}$} & $\begin{array}{l}0 \quad-\quad 0 \quad \% \\
\text { upravených } \\
\text { učebných osnov } \\
\text { pre UR }\end{array}$ & \multirow[t]{3}{*}{2} & \multirow[t]{3}{*}{2} & \multirow[t]{3}{*}{2} \\
\hline & & $\begin{array}{l}1-1 \text { až } 10 \% \\
\text { upravených } \\
\text { učebných osnov } \\
\text { pre UR }\end{array}$ & & & \\
\hline & & $\begin{array}{l}2-11 \text { až } 30 \% \\
\text { upravených } \\
\text { učebných osnov } \\
\text { pre UR }\end{array}$ & & & \\
\hline \multirow[t]{3}{*}{$\begin{array}{l}\text { Úprava } \\
\text { tematických } \\
\text { plánov pre } \\
\text { UR }\end{array}$} & \multirow{3}{*}{$\begin{array}{l}\text { Zaradenie tém UR } \\
\text { a globálnych tém } \\
\text { do tematických } \\
\text { plánov jednotlivých } \\
\text { vyučovacích } \\
\text { predmetov } \\
\text { (úprava } \\
\text { tematických plánov } \\
\text { predmetov } \\
\text { v percentách). }\end{array}$} & $\begin{array}{l}0-0 \text { až } 30 \% \\
\text { upravených } \\
\text { tematických } \\
\text { plánov pre UR }\end{array}$ & \multirow[t]{3}{*}{2} & \multirow[t]{3}{*}{1} & \multirow[t]{3}{*}{1} \\
\hline & & $\begin{array}{l}1-31 \text { až } 60 \% \\
\text { upravených } \\
\text { tematických } \\
\text { plánov pre UR }\end{array}$ & & & \\
\hline & & $\begin{array}{l}2-61 \text { až } 100 \\
\% \text { upravených } \\
\text { tematických } \\
\text { plánov pre UR }\end{array}$ & & & \\
\hline SPOLU & \multicolumn{2}{|c|}{ Max. 6 bodov (100 \%) } & 5 & 4 & 4 \\
\hline
\end{tabular}


Výsledky z hodnotenia kategórie I. Predmetová výchova a vzdelávanie (tab. 3) ukázali, že úroveň UR je na ZŠ J. Horáka a Cirkevnej ZŠ sv. F. Assiského na dobrej úrovni, na ZŠ J. Kollára na vel'mi dobrej úrovni. Hodnotenie týchto indikátorov bolo možné len v spolupráci s celým učitel'ským zborom, nakol'ko každý predmet ako aj úprava učebných osnov a tematických plánov je v individuálnej réžii každého učitel'a, čiže percentuálne výpočty sú výsledkom vychádzajúcim z podkladov pre hodnotený školský rok a ich následným porovnaním s dokumentmi z predošlého školského roku.

Ked’že ciel'om výchovy k udržatel'nému rozvoju je dosiahnutie kompetentnosti jednotlivca pochopit́ globálny charakter problémov ludstva a riešit́ aktuálne problémy na lokálnej úrovni (Halašová, Vincíková, 2008), dôrazným včlenením daných tém prierezovo do celého výchovno-vzdelávacieho procesu v rámci predmetovej dotácie ako aj úpravou tematických plánov, môžeme výrazne zlepšit́ dosahovanie daného výsledku. Žiaci si dané témy osvojujú prirodzene a primerane svojim schopnostiam a danostiam, pričom témy súvisiace s filozofiou udržatel'ného rozvoja sa dajú včlenit' takmer do všetkých predmetov vyučovaných na základných školách.

Na základe vyhodnotenia indikátorov môžeme konštatovat', že myšlienka a filozofia udržatel'ného rozvoja je súčast́ou výchovno-vzdelávacieho procesu na všetkých sledovaných školách. Žiakom je na škole ponúknuté rozšírené vzdelávanie v oblastiach súvisiacich S UR zavedením volitel'ných predmetov, a to: Environmentálna výchova, Regionálna výchova a tradičná l'udová kultúra a Ochrana života človeka a zdravia. Školy majú možnost́ zapojit' sa aj do projektu "Zelená škola", čo v súčasnosti už urobila ZŠ J. Kollára, ktorá je práve $v$ certifikačnom procese.

Tab. 3 Vyhodnotenie indikátorov I. Predmetová výchova a vzdelávanie za školský rok 2011/2012

\begin{tabular}{|l|l|l|l|}
\hline $\begin{array}{l}\text { CELKOVÁ } \\
\text { BODOVÁ } \\
\text { HODNOTA }\end{array}$ & $\begin{array}{l}\text { CELKOVÉ } \\
\text { HODNOTENIE }\end{array}$ & $\begin{array}{l}\text { SLOVNÉ } \\
\text { VYHODNOTENIE } \\
\text { INDIKÁTOROV }\end{array}$ & NÁZOV ŠKOLY \\
\hline 4 & $66,6 \%$ & Dobré & $\begin{array}{l}\text { ZŠ HORÁKA } \\
\text { ZŠ CIRKEVNÁ }\end{array}$ \\
\hline 5 & $83,3 \%$ & Vel'mi dobré & ZŠ KOLLÁRA \\
\hline
\end{tabular}

Na základe 9 indikátorov: Participácia žiakov na realizácii cielov a úloh politiky UR, Realizácia odbornej činnosti žiakov pre UR, Realizácia záujmových krúžkov pre UR, Úroveň realizácie aktivít pre UR, Realizácia školských aktivít pre UR, Realizácia celoškolských tematicky orientovaných aktivít pre UR, Realizácia aktivít pre UR s účastou verejnosti, Realizácia aktivít pre UR v spolupráci s verejnostou, Účast' na aktivitách pre UR organizovaných verejnostóu bola hodnotená druhá kategória Mimoškolská výchova a vzdelávanie. Tabulka 4. názorne dokumentuje hodnotenie súboru indikátorov $v$ tejto kategórií. 
Tab. 4 Hodnotenie základných škôl podl’a indikátorov II. Mimoškolská výchova a vzdelávanie za školský rok 2011/2012

\begin{tabular}{|c|c|c|c|c|c|}
\hline \multirow[b]{2}{*}{ Indikátor } & \multirow[b]{2}{*}{$\begin{array}{l}\text { Charakteristika } \\
\text { Indikátora }\end{array}$} & \multirow[b]{2}{*}{$\begin{array}{l}\text { Hodnotiace } \\
\text { Kritérium }\end{array}$} & \multicolumn{3}{|c|}{ Názov základnej školy } \\
\hline & & & $\begin{array}{l}\text { Zš } \\
\text { Kollára }\end{array}$ & $\begin{array}{l}\text { Zš } \\
\text { Horáka }\end{array}$ & $\begin{array}{l}\text { Zš } \\
\text { cirkevná } \\
\text { Assiského }\end{array}$ \\
\hline $\begin{array}{l}\text { Participácia } \\
\text { žiakov na } \\
\text { realizácii ciel'ov } \\
\text { a úloh politiky } \\
\text { UR }\end{array}$ & $\begin{array}{l}\text { Percento žiakov } \\
\text { aktívne zapojených } \\
\text { do realizácie ciel'ov } \\
\text { a úloh politiky UR } \\
\text { v rámci ich } \\
\text { mimoškolskej } \\
\text { činnosti (účast' na } \\
\text { environmentálnom } \\
\text { audite školy, } \\
\text { tvorba } \\
\text { propagačných } \\
\text { materiálov, osveta } \\
\text { verejnosti, } \\
\text { brigádnická činnost' } \\
\text { - čistenie, } \\
\text { skrášl'ovanie } \\
\text { životného } \\
\text { prostredia). }\end{array}$ & 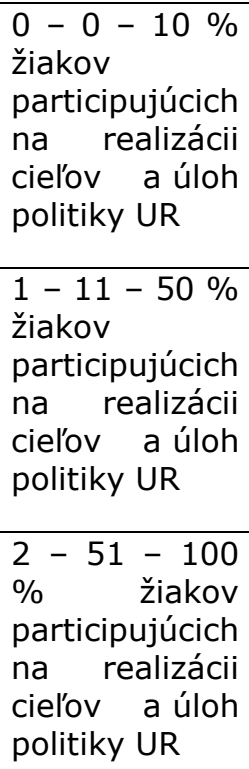 & 2 & 1 & 1 \\
\hline $\begin{array}{l}\text { Realizácia } \\
\text { odbornej } \\
\text { činnosti žiakov } \\
\text { pre UR }\end{array}$ & 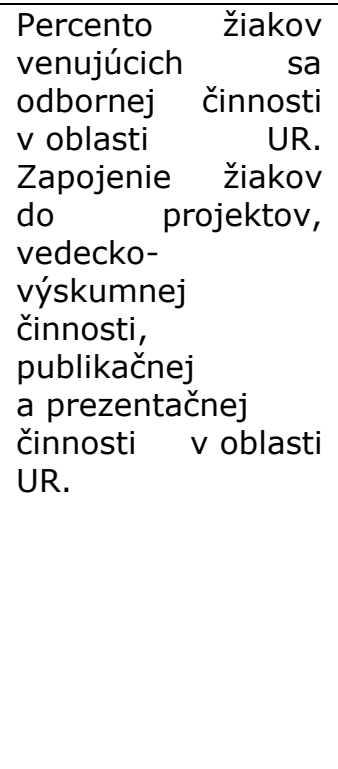 & 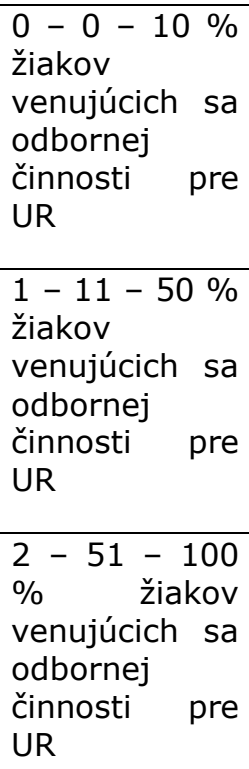 & 0 & 1 & 0 \\
\hline $\begin{array}{l}\text { Realizácia } \\
\text { záujmových } \\
\text { krúžkov pre UR }\end{array}$ & $\begin{array}{l}\text { Počet záujmových } \\
\text { krúžkov } \\
\text { realizovaných na } \\
\text { škole so zaradením } \\
\text { globálnych tém }\end{array}$ & $\begin{array}{l}0 \\
\text { realizovaný } \\
\text { jeden } \\
\text { záujmový } \\
\text { krúžok pre UR }\end{array}$ & 0 & 0 & 0 \\
\hline
\end{tabular}




\begin{tabular}{|c|c|c|c|c|c|}
\hline & $\begin{array}{l}\text { a praktických } \\
\text { aktivít } \\
\text { podporujúcich UR. }\end{array}$ & $\begin{array}{l}1 \\
\text { realizované } \\
\text { min. } \\
\text { záujmové tri } \\
\text { krúžky pre UR }\end{array}$ & & & \\
\hline & & $\begin{array}{l}2 \\
\text { realizovaných } \\
\text { aspoň pät' } \\
\text { záujmových } \\
\text { krúžkov pre } \\
\text { UR }\end{array}$ & & & \\
\hline \multirow[t]{3}{*}{$\begin{array}{l}\text { Pôsobnost' } \\
\text { realizácie } \\
\text { aktivít pre UR }\end{array}$} & \multirow{3}{*}{$\begin{array}{l}\text { Realizácia aktivít } \\
\text { v oblasti UR } \\
\text { (výstavy, sút́aže, } \\
\text { podujatia, } \\
\text { kampane) } \\
\text { organizovaných } \\
\text { školou na školskej, } \\
\text { regionálnej, } \\
\text { národnej úrovni. }\end{array}$} & $\begin{array}{l}0-\text { aktivity } \\
\text { pre UR } \\
\text { realizované } \\
\text { na školskej } \\
\text { úrovni }\end{array}$ & \multirow[t]{3}{*}{1} & \multirow[t]{3}{*}{1} & \multirow[t]{3}{*}{1} \\
\hline & & $\begin{array}{l}1-\text { aktivity } \\
\text { pre UR } \\
\text { realizované } \\
\text { na regionálnej } \\
\text { úrovni }\end{array}$ & & & \\
\hline & & $\begin{array}{l}2-\text { aktivity } \\
\text { pre UR } \\
\text { realizované } \\
\text { na národnej } \\
\text { úrovni }\end{array}$ & & & \\
\hline \multirow[t]{3}{*}{$\begin{array}{l}\text { Realizácia } \\
\text { školských } \\
\text { aktivít pre UR }\end{array}$} & \multirow[t]{3}{*}{$\begin{array}{l}\text { Počet aktivít } \\
\text { v oblasti } \\
\text { organizovaných } \\
\text { a realizovaných na } \\
\text { školskej úrovni. }\end{array}$} & $\begin{array}{lr}0 \quad- & \text { žiadna } \\
\text { aktivita pre } \\
\text { UR } \\
\text { realizovaná } \\
\text { na školskej } \\
\text { úrovni }\end{array}$ & \multirow[t]{3}{*}{2} & \multirow[t]{3}{*}{2} & \multirow[t]{3}{*}{1} \\
\hline & & $\begin{array}{l}1 \quad-\quad \text { aspoň } \\
\text { jedna aktivita } \\
\text { pre UR } \\
\text { realizované } \\
\text { na školskej } \\
\text { úrovni }\end{array}$ & & & \\
\hline & & $\begin{array}{l}2 \text { - minimálne } \\
\text { tri aktivity pre } \\
\text { UR } \\
\text { realizované } \\
\text { na školskej } \\
\text { úrovni }\end{array}$ & & & \\
\hline \multirow{2}{*}{$\begin{array}{l}\text { Realizácia } \\
\text { celoškolských } \\
\text { tematicky } \\
\text { orientovaných } \\
\text { aktivít pre UR }\end{array}$} & \multirow{2}{*}{$\begin{array}{lr}\text { Počet } & \text { aktivít } \\
\text { v oblasti } & \text { UR } \\
\text { organizovaných } & \\
\text { a realizovaných } & \\
\text { školou } & \text { so }\end{array}$} & $\begin{array}{lr}0 \quad- & \text { žiadna } \\
\text { aktivita } & \text { pre } \\
\text { UR } & \end{array}$ & \multirow[t]{2}{*}{2} & \multirow[t]{2}{*}{2} & \multirow[t]{2}{*}{1} \\
\hline & & $\begin{array}{lrr}1 & - & \text { aspoň } \\
\text { jedna } & \text { aktivita }\end{array}$ & & & \\
\hline
\end{tabular}




\begin{tabular}{|c|c|c|c|c|c|}
\hline & $\begin{array}{l}\text { zapojením } \\
\text { všetkých subjektov } \\
\text { školy venovaných } \\
\text { medzinárodným } \\
\text { a globálnym } \\
\text { témam. }\end{array}$ & $\begin{array}{l}\text { pre UR } \\
2 \text { - minimálne } \\
\text { tri aktivity pre } \\
\text { UR }\end{array}$ & & & \\
\hline \multirow[t]{3}{*}{$\begin{array}{l}\text { Realizácia } \\
\text { aktivít pre UR } \\
\text { s účastou } \\
\text { verejnosti }\end{array}$} & \multirow{3}{*}{$\begin{array}{l}\text { Počet aktivít } \\
\text { v oblasti } \quad \text { UR } \\
\text { organizovaných } \\
\text { školou s účastou } \\
\text { širokej verejnosti. }\end{array}$} & $\begin{array}{lr}0 & - \\
\text { aktivita } & \text { pre } \\
\text { UR } & \end{array}$ & \multirow[t]{3}{*}{2} & \multirow[t]{3}{*}{1} & \multirow[t]{3}{*}{1} \\
\hline & & $\begin{array}{l}1 \quad-\text { aspoň } \\
\text { jedna aktivita } \\
\text { pre UR }\end{array}$ & & & \\
\hline & & $\begin{array}{l}2 \text { - minimálne } \\
\text { tri aktivity pre } \\
\text { UR }\end{array}$ & & & \\
\hline \multirow[t]{3}{*}{$\begin{array}{l}\text { Realizácia } \\
\text { aktivít pre UR } \\
\text { v spolupráci } \\
\text { s verejnostou }\end{array}$} & \multirow{3}{*}{$\begin{array}{l}\text { Počet aktivít } \\
\text { v oblasti UR } \\
\text { organizovaných } \\
\text { školou v spolupráci } \\
\text { so širokou } \\
\text { verejnost́ou. }\end{array}$} & 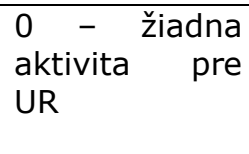 & \multirow[t]{3}{*}{1} & \multirow[t]{3}{*}{1} & \multirow[t]{3}{*}{1} \\
\hline & & $\begin{array}{l}1 \quad-\text { aspoň } \\
\text { jedna aktivita } \\
\text { pre UR }\end{array}$ & & & \\
\hline & & $\begin{array}{l}2 \text { - minimálne } \\
\text { tri aktivity pre } \\
\text { UR }\end{array}$ & & & \\
\hline \multirow{3}{*}{$\begin{array}{l}\text { Účast' na } \\
\text { aktivitách } \\
\text { pre UR } \\
\text { organizovaných } \\
\text { verejnost́ou }\end{array}$} & \multirow{3}{*}{ 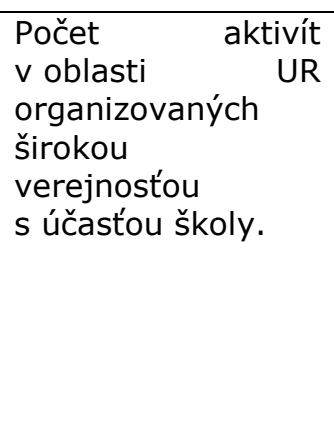 } & $\begin{array}{lr}0 & - \\
\text { aktiviadna } \\
\text { UR }\end{array}$ & \multirow[t]{3}{*}{1} & \multirow[t]{3}{*}{2} & \multirow[t]{3}{*}{1} \\
\hline & & $\begin{array}{l}1 \quad-\text { aspoň } \\
\text { jedna aktivita } \\
\text { pre UR }\end{array}$ & & & \\
\hline & & $\begin{array}{l}2 \text { - minimálne } \\
\text { tri aktivity pre } \\
\text { UR }\end{array}$ & & & \\
\hline SPOLU & \multicolumn{2}{|c|}{ Max. 18 bodov (100 \%) } & 11 & 11 & 7 \\
\hline
\end{tabular}

\section{Výsledky z vyhodnotenia kategórie II.}

Mimoškolská výchova a vzdelávanie (tab. 5) ukázali, že úroveň UR bola v hodnotenom období školského roka 2011/2012 na dvoch hodnotených školách na dobrej úrovni a na jednej škole na neuspokojivej úrovni. Na školách prebiehali počas školského roka aktivity pre UR, a to $v$ rámci školskej aj mimoškolskej činnosti. Ked'že každá škola je súčastón miestnej komunity, jej úlohou by malo byt́ napíňanie aj úloh, ktoré sú v súlade s komunitným rozvojom a Miestnou agendou 21, ktorú sa Slovenská republika zaviazala napíňat'. Pre zlepšenie súčasného stavu odporúčame preto školám lepšiu spoluprácu s miestnou komunitou, ktorá zabezpečí zvýšenie kvality zručností a návykov, ktoré si žiaci osvoja pri realizácii konkrétnych aktivít. Rovnako je tu priestor pre rôzne záujmové krúžky 
a mimoškolskú činnost́. Na jednotlivých školách sa síce realizuje, nemá však charakter sústavnej, periodickej činnosti, ale je vykonávaná príležitostne (zber papiera a iných druhotných surovín, exkurzie, návšteva tvorivých dielní a pod.)

Tab. 5 Vyhodnotenie indikátorov II. Mimoškolská výchova a vzdelávanie za školský rok 2011/2012

\begin{tabular}{|l|l|l|l|}
\hline $\begin{array}{l}\text { CELKOVÁ } \\
\text { BODOVÁ } \\
\text { HODNOTA }\end{array}$ & $\begin{array}{l}\text { CELKOVÉ \% } \\
\text { HODNOTENIE }\end{array}$ & $\begin{array}{l}\text { SLOVNÉ VYHODNOTENIE } \\
\text { INDIKÁTOROV }\end{array}$ & NÁZOV ŠKOLY \\
\hline 7 & $38,9 \%$ & Neuspokojivé & ZŠ CIRKEVNÁ \\
\hline 11 & $61,1 \%$ & Dobré & $\begin{array}{l}\text { ZŠ KOLLÁRA } \\
\text { ZŠ HORÁKA }\end{array}$ \\
\hline
\end{tabular}

Tretia kategória Kvalita výchovy a vzdelávania bola hodnotená na základe 7 indikátorov: Implementácia environmentálneho aspektu UR, Implementácia sociálneho aspektu UR, Implementácia ekonomického aspektu UR, Zavádzanie nových vyučovacích metód, Zabezpečenie odbornej literatúry pre UR, Technické zabezpečenie pre UR, Využívanie informačno-komunikačných prostriedkov pre UR. Hodnotenie súboru indikátorov v tretej kategórií dokumentuje nasledovná tabulka 6.

Tab. 6 Hodnotenie základných škôl podl’a indikátorov III. Kvalita výchovy a vzdelávania za školský rok 2011/2012

\begin{tabular}{|c|c|c|c|c|c|}
\hline \multirow[b]{2}{*}{ INDIKÁTOR } & \multirow[b]{2}{*}{$\begin{array}{l}\text { CHARAKTERISTIKA } \\
\text { INDIKÁTORA }\end{array}$} & \multirow[b]{2}{*}{$\begin{array}{l}\text { HODNOTIACE } \\
\text { KRITÉRIUM }\end{array}$} & \multicolumn{3}{|c|}{ NÁZOV ZÁKLADNEJ ŠKOLY } \\
\hline & & & $\begin{array}{l}\text { ZŠ } \\
\text { KOLLÁRA }\end{array}$ & $\begin{array}{l}\text { ZŠ } \\
\text { HORÁKA }\end{array}$ & $\begin{array}{l}\text { ZŚ } \\
\text { CIRKEVNÁ } \\
\text { ASSISKÉHO }\end{array}$ \\
\hline \multirow[t]{3}{*}{$\begin{array}{l}\text { Implementáci } \\
\text { a } \\
\text { environmentál } \\
\text {-neho aspektu } \\
\text { UR }\end{array}$} & \multirow{3}{*}{$\begin{array}{l}\text { Implementácia } \\
\text { enviro. globál. tém } \\
\text { UR (ochrana ŽP, } \\
\text { využívanie } \\
\text { prírodných zdrojov, } \\
\text { alternatívne zdroje } \\
\text { energií, biodiverzita, } \\
\text { klimatické zmeny...) } \\
\text { v rámci predmetovej } \\
\text { a mimoškolskej } \\
\text { výchovy } \\
\text { a vzdelávania. }\end{array}$} & $\begin{array}{l}0 \quad-\quad \text { žiadna } \\
\text { implementácia } \\
\text { enviro. aspektu } \\
\text { UR }\end{array}$ & \multirow[t]{3}{*}{2} & \multirow[t]{3}{*}{2} & \multirow[t]{3}{*}{1} \\
\hline & & $\begin{array}{l}1 \\
\text { implementácia } \\
\text { do predmetovej } \\
\text { alebo } \\
\text { mimoškolskej } \\
\text { výchovy } \\
\text { a vzdelávania }\end{array}$ & & & \\
\hline & & $\begin{array}{l}2 \\
\text { implementácia } \\
\text { do predmetovej } \\
\text { a mimoškolskej } \\
\text { výchovy a } \\
\text { vzdelávania }\end{array}$ & & & \\
\hline Implementáci & Implementácia & žiadna & & & \\
\hline
\end{tabular}




\begin{tabular}{|c|c|c|c|c|c|}
\hline \multirow[t]{3}{*}{$\begin{array}{l}\text { a sociálneho } \\
\text { aspektu UR }\end{array}$} & \multirow{3}{*}{$\begin{array}{l}\text { globál. tém UR } \\
\text { (chudoba, } \\
\text { nerovnost', } \\
\text { spravodlivost', } \\
\text { l'udské práva, } \\
\text { demokracia...) } \\
\text { v rámci predmetovej } \\
\text { a mimoškolskej } \\
\text { výchovy } \\
\text { a vzdelávania. }\end{array}$} & $\begin{array}{l}\text { implementácia } \\
\text { soc. aspektu UR }\end{array}$ & \multirow[t]{3}{*}{1} & \multirow[t]{3}{*}{1} & \multirow[t]{3}{*}{2} \\
\hline & & $\begin{array}{l}1 \\
\text { implementácia } \\
\text { do predmetovej } \\
\text { alebo } \\
\text { mimoškolskej } \\
\text { výchovy } \\
\text { a vzdelávania }\end{array}$ & & & \\
\hline & & $\begin{array}{l}2 \text { - } \\
\text { implementácia } \\
\text { do predmetovej } \\
\text { a mimoškolskej } \\
\text { výchovy a } \\
\text { vzdelávania }\end{array}$ & & & \\
\hline \multirow[t]{3}{*}{$\begin{array}{l}\text { Implementáci } \\
\text { a } \\
\text { ekonomického } \\
\text { aspektu UR }\end{array}$} & \multirow{3}{*}{$\begin{array}{l}\text { Implementácia } \\
\text { ekonomických } \\
\text { globál. tém UR } \\
\text { (rozvoj obcí, } \\
\text { spotreba, výroba, } \\
\text { ekonomická } \\
\text { globalizácia...) } \\
\text { v rámci predmetovej } \\
\text { a mimoškolskej } \\
\text { výchovy } \\
\text { a vzdelávania } \\
\text { škole. }\end{array}$} & $\begin{array}{l}0 \quad-\quad \text { žiadna } \\
\text { implementácia } \\
\text { ekonom. } \\
\text { aspektu UR }\end{array}$ & \multirow[t]{3}{*}{1} & \multirow[t]{3}{*}{1} & \multirow[t]{3}{*}{2} \\
\hline & & $\begin{array}{l}1 \\
\text { implementácia } \\
\text { do predmetovej } \\
\text { alebo } \\
\text { mimoškolskej } \\
\text { výchovy } \\
\text { a vzdelávania }\end{array}$ & & & \\
\hline & & $\begin{array}{l}2 \\
\text { implementácia } \\
\text { do predmetovej } \\
\text { a mimoškolskej } \\
\text { výchovy a } \\
\text { vzdelávania }\end{array}$ & & & \\
\hline \multirow{3}{*}{$\begin{array}{l}\text { Zavádzanie } \\
\text { aktivizujúcich } \\
\text { vyučovacích } \\
\text { metód } \\
\text { a foriem do } \\
\text { výchovno- } \\
\text { vzdelávacieho } \\
\text { procesu }\end{array}$} & \multirow{3}{*}{$\begin{array}{l}\text { Zavádzanie } \\
\text { aktivizujúcich } \\
\text { výchovno- } \\
\text { vzdelávacích metód } \\
\text { a foriem do výučby } \\
\text { (hry- inscenačné, } \\
\text { situačné, diskusie, } \\
\text { brainstorming, } \\
\text { projektové } \\
\text { vyučovanie, } \\
\text { exkurzie, skupinová } \\
\text { práca...). }\end{array}$} & $\begin{array}{l}0 \quad-\quad \text { žiadne } \\
\text { aktivizujúce } \\
\text { vyučovacie } \\
\text { metódy a formy }\end{array}$ & \multirow[t]{3}{*}{1} & \multirow[t]{3}{*}{1} & \multirow[t]{3}{*}{1} \\
\hline & & $\begin{array}{l}1 \text { - zavádzanie } \\
\text { aktivizujúcich } \\
\text { vyučovacích } \\
\text { metód a foriem } \\
\text { do niektorých } \\
\text { predmetov }\end{array}$ & & & \\
\hline & & $\begin{array}{l}2 \text { - zavádzanie } \\
\text { aktivizujúcich } \\
\text { vyučovacích } \\
\text { metód a foriem } \\
\text { do všetkých } \\
\text { predmetov }\end{array}$ & & & \\
\hline
\end{tabular}




\begin{tabular}{|c|c|c|c|c|c|}
\hline \multirow[t]{2}{*}{$\begin{array}{l}\text { Zabezpečenie } \\
\text { odbornej } \\
\text { literatúry pre } \\
\text { UR }\end{array}$} & \multirow[t]{2}{*}{$\begin{array}{lc}\text { Vybavenost' } & \text { školy } \\
\text { odbornou, } & \\
\text { metodickou } & \\
\text { literatúrou } & \text { pre } \\
\text { výchovu } & \\
\text { a vzdelávanie } & \text { k UR. }\end{array}$} & $\begin{array}{l}\begin{array}{l}0 \\
\text { zabezpečenie } \\
\text { literatúry pre } \\
\text { UR }\end{array} \\
1 \text { zabezpečenie } \\
\begin{array}{l}\text { niektorých } \\
\text { predmetov } \\
\text { odbornou lit. } \\
\text { pre UR }\end{array}\end{array}$ & \multirow[t]{2}{*}{1} & \multirow[t]{2}{*}{1} & \multirow[t]{2}{*}{1} \\
\hline & & $\begin{array}{ll}2 & - \\
\text { zabezpečenie } & \\
\text { všetkých } & \\
\text { predmetov } & \\
\text { odbornou lit. } \\
\text { pre UR }\end{array}$ & & & \\
\hline $\begin{array}{l}\text { Materiálno- } \\
\text { technické } \\
\text { zabezpečenie } \\
\text { pre UR }\end{array}$ & $\begin{array}{l}\text { Materiálno- } \\
\text { technického } \\
\text { zabezpečenie a } \\
\text { vybavenie priestorov } \\
\text { školy. Vybavenost' } \\
\text { školy technickými } \\
\text { pomôckami (počítač, } \\
\text { dataprojektor, } \\
\text { interaktívna tabul'a) } \\
\text { pre výchovu } \\
\text { a vzdelávanie k UR. }\end{array}$ & 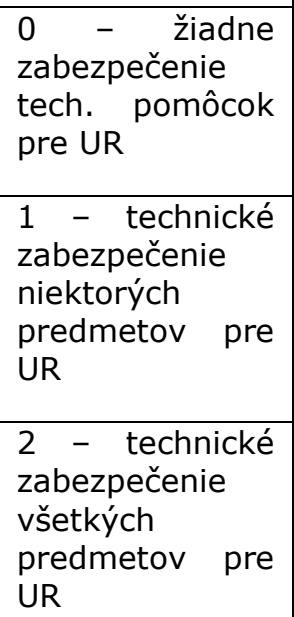 & 1 & 1 & 1 \\
\hline $\begin{array}{l}\text { Využívanie } \\
\text { informačno- } \\
\text { komunikač- } \\
\text { ných } \\
\text { prostriedkov } \\
\text { pre UR }\end{array}$ & $\begin{array}{l}\text { Využívanie } \\
\text { školského rozhlasu, } \\
\text { časopisu, násteniek, } \\
\text { internetu a knižnice } \\
\text { pri vzdelávaní a } \\
\text { zvyšovaní } \\
\text { informovanosti a pre } \\
\text { skvalitnenie } \\
\text { komunikácie ako } \\
\text { základ UR. }\end{array}$ & $\begin{array}{l}\begin{array}{l}0 \quad-\quad \text { žiadne } \\
\text { využívanie } \\
\text { info.-kom. } \\
\text { prostriedkov } \\
\text { pre UR }\end{array} \\
1-\text { využívanie } \\
\text { niektorých } \\
\text { info.-kom. } \\
\text { prostriedkov } \\
\text { pre UR }\end{array}$ & 1 & 1 & 1 \\
\hline SPOLU & Max. 14 bodov (100\% & & 8 & 8 & 9 \\
\hline
\end{tabular}


Kvalita výchovy a vzdelávania je chápaná ako určitý stupeň dokonalosti. Mieru kvalitnosti možno vyjadrit' posudzovaním prvkov školského prostredia (napr. materiálnotechnické zabezpečenie, koncepcia školy, napĺn̆anie ciel'ov, výber učiva, využívanie didaktických metód a foriem vzdelávania, vzt́ahy učitelia, žiaci) (Bacík, 1993; Blaško, 2012).

$\mathrm{Na}$ základe vyhodnotenia kategórie III. Kvalita výchovy a vzdelávania (tab. 7) môžeme konštatovat́, že kvalita výchovy a vzdelávania v intenciách UR je na jednej škole na dobrej úrovni a na dvoch školách na uspokojivej úrovni. Témy UR sú implementované do vzdelávacieho procesu a školy majú vyhovujúce možnosti pre zabezpečenie výučby týchto tém. Rovnako sú využívané aj inovačné metódy a formy vo výchovno-vzdelávacom procese. Priestor vidíme v zlepšení vybavenosti škôl technickými pomôckami pre výchovu a vzdelávanie k UR a vo využívaní informačno-komunikačných prostriedkov. Navrhujeme klást' väčší dôraz aj na projektové vyučovanie, čo môže prispiet' $k$ zlepšeniu životného prostredia v škole, jej okolí, ako aj výchove k tímovej a tvorivej spolupráci.

Tab. 7 Vyhodnotenie indikátorov III. Kvalita výchovy a vzdelávania za školský rok 2011/2012

\begin{tabular}{|l|l|l|l|}
\hline $\begin{array}{l}\text { CELKOVÁ } \\
\text { BODOVÁ } \\
\text { HODNOTA }\end{array}$ & $\begin{array}{l}\text { CELKOVÉ \% } \\
\text { HODNOTENIE }\end{array}$ & $\begin{array}{l}\text { SLOVNÉ } \\
\text { VYHODNOTENIE } \\
\text { INDIKÁTOROV }\end{array}$ & NÁZOV ŠKOLY \\
\hline 8 & $57,1 \%$ & Uspokojivé & $\begin{array}{l}\text { ZŠ KOLLÁRA } \\
\text { ZŠ HORÁKA }\end{array}$ \\
\hline 9 & $64,3 \%$ & Dobré & ZŠ CIRKEVNÁ \\
\hline
\end{tabular}

\section{Záver}

$\mathrm{Na}$ základe hodnotenia indikátorov môžeme konštatovat', že školy zaradené do prieskumu sú na dobrej ceste pri uplatňovaní filozofie UR vo výchovno-vzdelávacom procese. Postupnými krokmi sa snažia rozvíjat' environmentálny profil a zároveň budovat' pozitívny citový vztáah mladých l'udí k prostrediu, k l'ud'om a k l'udským výtvorom a to predovšetkým prostredníctvom percepcie, vlastných zážitkov a osobných skúseností (Chrenščová, 2004).

ZŠ J. Kollára je zapojená od roku 2011 do projektu "Zelená škola" čo je certifikačnovzdelávací program, ktorý je súčast́ou celosvetovej siete Eco-Schools. Program "Zelená škola" (Živica, 2013) pomáha slovenským školám realizovat' environmentálnu výchovu prepojenú s praktickými krokmi. Tie vedú žiakov a celú školu k šetrnejšiemu prístupu voči životnému prostrediu t.j. pomáhajú znízit' celkový vplyv školy na životné prostredie. Zahŕňa celú školu spolu s členmi miestnej komunity a aktivuje ich participáciu na rozhodovaní a riešení vybraných problémov. Podporuje tímovú prácu a pomáha vytvárat́ spoločnú víziu školy, ktorá rešpektuje, rozvíja myšlienky udržatel'nosti a prakticky chráni životné prostredie. Žiaci sú súčastóou pracovného tímu - Kolégia. Navrhujú zlepšenia, ktoré sa snažia pri zapojení celej školskej komunity zrealizovat.. Všetky tri školy majú témy udržatel'ného rozvoja prierezovo zaradené do celého výchovno-vzdelávacieho procesu s ciel'om vysvetl'ovat' vzt́ahy a možnosti ochrany životného prostredia a naučit' aktívne využívat' vedomosti o vlastnom regióne $v$ prospech jeho ochrany a udržatel'ného rozvoja. 
Rozvíjajú u žiakov sociálne, etické a estetické cítenie, vedú ich $\mathrm{k}$ ohl'aduplnosti $\mathrm{k}$ hodnotám, ktoré vytvoril človek, ako aj k iným živým bytostiam. Učia ich vnímat' a tvorit' krásu v prírode, v medziludských vzt́ahoch a vedú ich ku skromnosti v materiálnej spotrebe. Na ZŠ J. Kollára a ZŠ J. Horáka je evidentná akcentácia environmentálnych tém prostredníctvom predmetu Environmentálna výchova a úspěšnej účasti na "Enviroprojekte" vyhlásenom Ministerstvom školstva SR. V rokoch 2009 a 2011 ZŠ J. Horáka realizovala projekty na inovatívne metodické pomôcky pre výučbu, ako aj pre zavádzanie a uvedomovanie si holistického nazerania na svet prostredníctvom projektu „Kolobeh živín". V roku 2012 bol schválený a realizovaný projekt aj na ZŠ J. Kollára s názvom "Dobrodružná cesta zdravých potravín", kde okrem environmentálnej témy bola presadzovaná podpora lokálnej produkcie a ekonomiky ako aj komunitnej spolupráce. Na Cirkevnej ZŠ sv. F. Assiského je zjavné presadzovanie sociálnej a spirituálnej dimenzie udržatel'ného rozvoja s dôrazom na spoznávanie kultúrneho dedičstva a regionálny rozvoj, čoho dôkazom je aj zaradenie volitel'ného predmetu Regionálna výchova a tradičná l'udová kultúra a Ochrana života človeka a zdravia. Aktuálne (február 2013) sa tejto základnej škole podarilo uspiet" v projektovej výzve "IKEA spolu s vami" s projektom "Tri svety". Cielom projektu je premenit' školskú záhradu na eko-plochu, kde budú organizované besiedky, hry, experimentálna výuka a podporovaná tímová spolupráca prostredníctvom spoločnej starostlivosti o záhradu s dopestovaním si vlastnej zeleniny. Do procesu budovania sa zapoja nielen učitelia spolu so žiakmi, ale aj rodičia a miestna komunita.

$\mathrm{Na}$ záver, vychádzajúc z hodnotenia troch kategórií Indikátorov výchovnovzdelávacieho procesu, odporúčame $v$ hodnotených školách nad’alej sledovat' a pravidelne evidovat' jednotlivé indikátory vo všetkých kategóriách, za účelom dosiahnutia neustáleho zlepšovania stavu uplatňovania myšlienok UR.

Použitý metodický postup je aplikovatel'ný aj pre iné školy (základné, stredné), prostredníctvom ktorého môžu uskutočnit' vlastný interný audit svojej úrovne UR a zároveň môže prispiet' pri kreovaní vízií smerovania školy s ciel'om zabezpečit' implementáciu filozofie UR do výchovno-vzdelávacieho procesu, respektíve zlepšit́ už existujúci stav. Inovácia metodiky vo vyhodnocovacej fáze prináša možnosti pre lepšie zistenie počiatočného stavu, vstupnej analýzy komplexne pre celý súbor Indikátorov UR, alebo aj čiastkové hodnotenie jednotlivých kategórií. Nevylučuje však d’alší výskum a sledovanie vývoja škôl smerom k udržatel'nému rozvoju podl'a metodiky Šimonovičovej, Šudý et al. (2008), ktorá bola aplikovaná pri hodnotení UR na Základnej škole Jozefa Gregora Tajovského v Banskej Bystrici (Rákayová, Tomaškinová, 2012). Otvára sa možnost' d'alšieho výskumu na hodnotených školách na základe výpočtu indexu stavu udržatel'ného rozvoja školy a porovnania výsledkov v školskom roku 2012 - 2013 s údajmi získanými za školský rok 2011 - 2012. Autorom pôvodnej metodiky Šimoničová, Šudý et al. (2008) odporúčame spresnit' percentuálne intervaly $v$ kritériách hodnotenia, nakolko nie sú stanovené jednoznačne, ako aj presnejšie a popisnejšie charakteristiky jednotlivých indikátorov.

\section{Literatúra}

- Bacík, F. (1983). Aktuální otázky ř́zení práce škol. Bratislava: SPN.

- Blaško, M. (2012). Úvod do modernej didaktiky II. (Manažérstvo kvality v škole). Košice: KIP TU. Retrieved from http://web.tuke.sk/kip/main.php?om $=1300 \& r e s=l o w \& m e n u=1310$

- Cviková, J., Dúbravová, V., Kaháthová, B., Lukšík, I, Medal, R., Návojský, A., Pietruchová, O, (2010). Mimovládne iniciatívy vo vzdelávaní. Ako mimovládne organizácie vstupujú do systému vzdelávania. Bratislava: Nadácia otvorenej spoločnosti.

- Eco-Schools. What are the Seven Steps? . . Retrieved from http://www.ecoschools.org/Menu/Process/Seven+Steps 
- Ekologická stopa školy . . Retrieved from http://ekostopa.sk/ekologicka-stopaskoly

- Halašová, M., \& Vincíková, S. (2008). Škola a miestna komunita v invenciách trvalo udržatel'ného rozvoja. Banská Bystrica: Fakulta prírodných vied Univerzita Mateja Bela.

- Halašová, M. (2011). Poznanie a vedy v kontexte kultivácie vztahu človeka k životnému prostrediu a koncepcie udržatel'nosti. Acta Universitatis Matthiae Belii, 13(2), 19-33.

- Chrenščová, V. (2004). Potreba ekologizácie základných škôl. Acta Universitatis Matthiae Belii, Séria Environmentálna ekológia, 6(1), 5-12.

- Kelcová, M., \& Ugrocká, M. (1996). Environmentálne minimum - učebné osnovy environmentálnej výchovy pre základné a stredné školy. Bratislava: ŠPU.

- Koncepcia environmentálnej výchovy a vzdelávania (1997). Bratislava: MŽP SR. Retrieved from http://www.spirala.sk/dokumenty/koncepcia.doc

- Národná stratégia pre globálne vzdelávanie na obdobie rokov 2012-2016 (2012). : Vláda SR. Retrieved from http://www.statpedu.sk/files/documents/odborne info/narodna strategia globalne \%20vzdelavanie 2012 2016.pdf

- Stratégia EHK OSN pre výchovu k trvalo udržatelnému rozvoju. Zasadanie na vysokej úrovni predstavitelov ministerstiev životného prostredia a školstva vo Vilniuse 17.-18.3.2005 . . Retrieved from http://www.unece.org/env/esd/strate/gytext/Slovak.pdf

- Šimonovičová, J., Šudý, M., Kasanická, L., \& Knapec, J. (2008). Indikátory trvalo udržatel'ného rozvoja škôl. Banská Bystrica: Univerzita Mateja Bela, Fakulta prírodných vied.

- ŠVP - EV_Pt (Štátny vzdelávací program - Environmentálna výchova Prierezová téma) (2009). . Retrieved from http://www.statpedu.sk/files/documents/svp/prierezove temy/environmentalna $v$ ychova.pdf

- Tomaškanová, J., \& Rákayová, M. (2012). Evaluácia stavu uplatňovania udržatel'ného rozvoja na báze indikátorov manažmentu. Acta Universitatis Matthiae Belii, 14(2), 37-45.

- Živica, (2013). Zelená škola. : Živica. Retrieved from http://www.zelenaskola.sk/co-je-zelena-skola/program-zelena-skola

- $\quad$ http://www.enviroschools.org.nz/

- $\quad$ http://www.greenschools.ca/

- http://www.seer.org/

- http://www.environment.gov.au/ (2013).

- se, h. w. h. . http://www.hsr.se/ . .

- http://www.footprintnetwork.org .. 
RNDr. Viera Chrenščová, PhD., Mgr. Jana Škvarková, Univerzita Komenského v Bratislave, Prírodovedecká fakulta, Katedra krajinnej ekológie, Mlynská dolina, 84215 Bratislava, e-mail: chrenscova@fns.uniba.sk, skvarkova@fns.uniba.sk 
Časopis Envigogika vydává Centrum pro otázky životního prostředí UK. Vývoj časopisu je podpořen projektem OP VK Mezioborová sít udržitelného rozvoje.

Více najdete na internetových stránkách projektu http://mosur.czp.cuni.cz
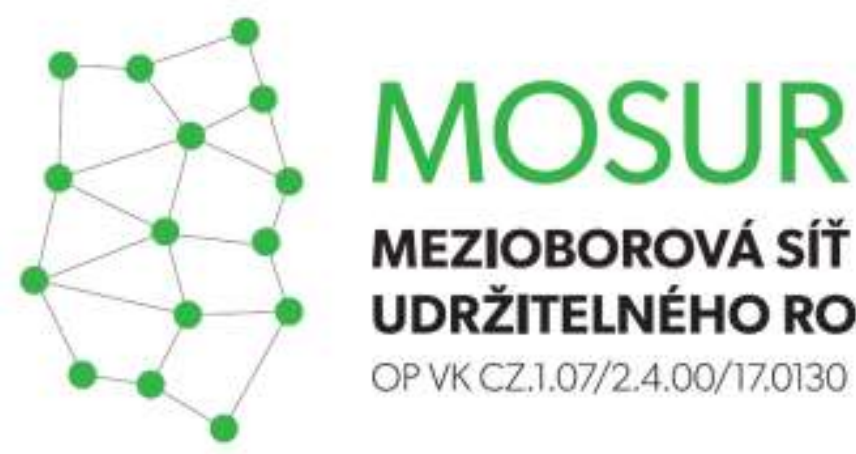

\section{MEZIOBOROVÁ SÍT}

UDRŽITELNÉHO ROZVOJE

OP VK CZ.1.07/2.4.00/17.0130
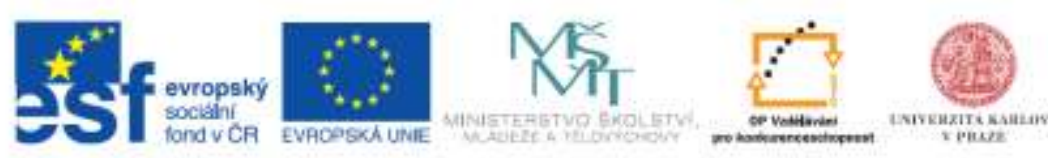

INVESTICE DO ROZVOJE VZDELAVANI 